\title{
Evaluation of the quality of cow milk consumed by children in and around Bahir Dar
}

\author{
Fanaye Shiferaw $^{1}$, Ashenafi Mengistu ${ }^{2}$, Getachew Terefe ${ }^{2}$, Hailu Mazengia ${ }^{3^{*}}$ \\ ${ }^{1}$ Debre Birhan University, College of Agriculture and Natural Resource \\ ${ }^{2}$ Addis Ababa University, College of Veterinary Medicine and Agriculture \\ ${ }^{3}$ Bahir Dar University, College of Agriculture and Environmental Sciences
}

\begin{abstract}
The safety of dairy products with respect to food-borne diseases is a great public health concern around the world. The microbial load of milk is a major factor in determining its quality. Hence, this study was aimed to evaluate of the quality and hygienic practices of cow milk consumed by children in and around Bahir Dar. A total of 79 milk samples were collected and analyzed using standard bacteriological examination. The study revealed that the proportions of respondents who practice udder washing prior to milking were $56 \%, 22 \%$ and $2 \%$ in urban, periurban and rural areas, respectively. Moreover, $88.7 \%, 67.3 \%$ and $45.2 \%$ of respondents has a practice of milk boiling before feeding the milk to their children in the urban, peri-urban and rural areas of the study, respectively. The majority of respondents in the urban (88\%) and peri-urban (50\%) areas wash milking, milk feeding and storing containers with detergents and boiled water. Higher (SPC/ml) was found in the rural $5 \times 10^{5}$ areas of the study compared to the urban and peri-urban sites. Likewise, of SPC, higher CC $\left(2.2 \times 10^{5}\right)$ was obtained in the rural area of the study without significant $(\mathrm{p}>0.05)$ difference in mean SPC across location. Therefore, milk collected from all study sites does not meet the minimum quality standard as the coliform population was much higher than the value indicated. Therefore, further research works to address constraints and to improve child milk consumption are imperative.
\end{abstract}

Keywords: Bahir Dar, child milk consumption, milk quality

DOI: http://dx.doi.org/10.4314/ejst.v8i2.2

\section{INTRODUCTION}

Milk is one of the major products of livestock (cattle, camels and goat).In addition to serving as source of income for livestock owners; it can contribute to household food security especially for healthy child nutrition. Milk is a nutrient dense food and is known to contribute a high proportion of the nutrients, such as high quality protein and micronutrients (Barasa, 2008). However, milk provides are an ideal medium for growth of bacteria. The hygienic control of milk and milk product in Ethiopia is not usually conducted on routine bases (Bisrat Godefay and Bayleyegn Molla, 2000).

The safety of dairy products with respect to foodborne diseases is of great concern around the world. The microbial load of milk is a major factor in deter- mining its quality. It indicates the hygienic level exercised during milking, that is, cleanliness of the milking utensils, condition of storage, manner of transport as well as the cleanliness of the udder of the individual animal (Parekin and Subhash, 2008).

According to Bisrat Godefay and Bayleyegn Molla (2000), in Ethiopia the dairy hygiene is given less attention. They reported that, exogenous sources of milk contamination with bacteria are very common. According to Asaminew Tassew (2007), the overall milking hygienic practice followed by the farmers in Bahir Dar Zuria and Mecha Woreda is poor. But, provision of milk and milk products of good hygienic quality and quantity is desirable from consumer health point of view (Zelalem Yilma, 2010). Therefore; this study was conducted with objectives of evaluating quality of cow milk consumed by children in and around Bahir Dar.

\footnotetext{
*Corresponding author:hailumakida@yahoo.com

(C) This is an Open Access article distributed under the terms of the Creative Commons Attribution License (http://creativecommons.org/licenses/CC BY4.0)
} 


\section{MATERIALS AND METHODS}

\section{Description of the study area}

Bahir Dar is the capital of Amhara National Regional State, located at about $565 \mathrm{~km}$ away from Addis Ababa (Figure 1). The Regional State covers a total area of $152,600 \mathrm{~km}^{2}$. The Region has 10.6 million cattle, 5.7 million sheep, 4 million goats, 2.1 million equines and 17,400 camels managed under extensive management system (BoFED, 2008). Bahir Dar City is located at 11 " $38^{\prime} \mathrm{N}, 37$ " $10^{\prime} \mathrm{E}$ on the South of Lake Tana where Blue Nile River starts. The elevation reported for the City is about 1801 m.a.s.l. There are 9 kebeles in the City (QCB, 2010). The area receives an average annual rainfall ranging between $850 \mathrm{~mm}$ to $1250 \mathrm{~mm}$ with the minimum and maximum average daily temperatures of $10^{\circ} \mathrm{c}$ and $32^{\circ} \mathrm{c}$, respectively (BoARD, 2006). According to the BCAO (2012/13), the population of Bahir Dar is about 220,344 (includ- ing rural kebeles). When disaggregated by place of settlement, the rural population of Bahir Dar constituted 40,250 while the urban population is 180,094 . According to the ALZR (2012/13), the peri urban and rural area of Bahir Dar has 39 kebele administrations with total human population 230,432 (133,707 male and 96,725 females). These kebeles are located at an altitude of 1500-1800 m. a. s. 1 with mean annual rainfall of $800-1250 \mathrm{~mm}$ and mean annual temperature of $28-32^{\circ} \mathrm{C}$. The minimum and maximum average daily temperature of the kebeles is $10^{\circ} \mathrm{c}$ and $32^{\circ} \mathrm{c}$, respectively (BZOARD, 2007). Uncultivated lands due to various reasons are estimated to 31,271 $\mathrm{km}^{2}$. The livestock population of peri urban and rural areas of Bahir Dar is estimated to be 206,865 cattle, 14,329 sheep, 26,049 goats, 18,728 donkeys, 716 mule and 346,546 poultry. Furthermore, there are about 19,706 honeybee colonies found in the Woreda (CACC, 2003).

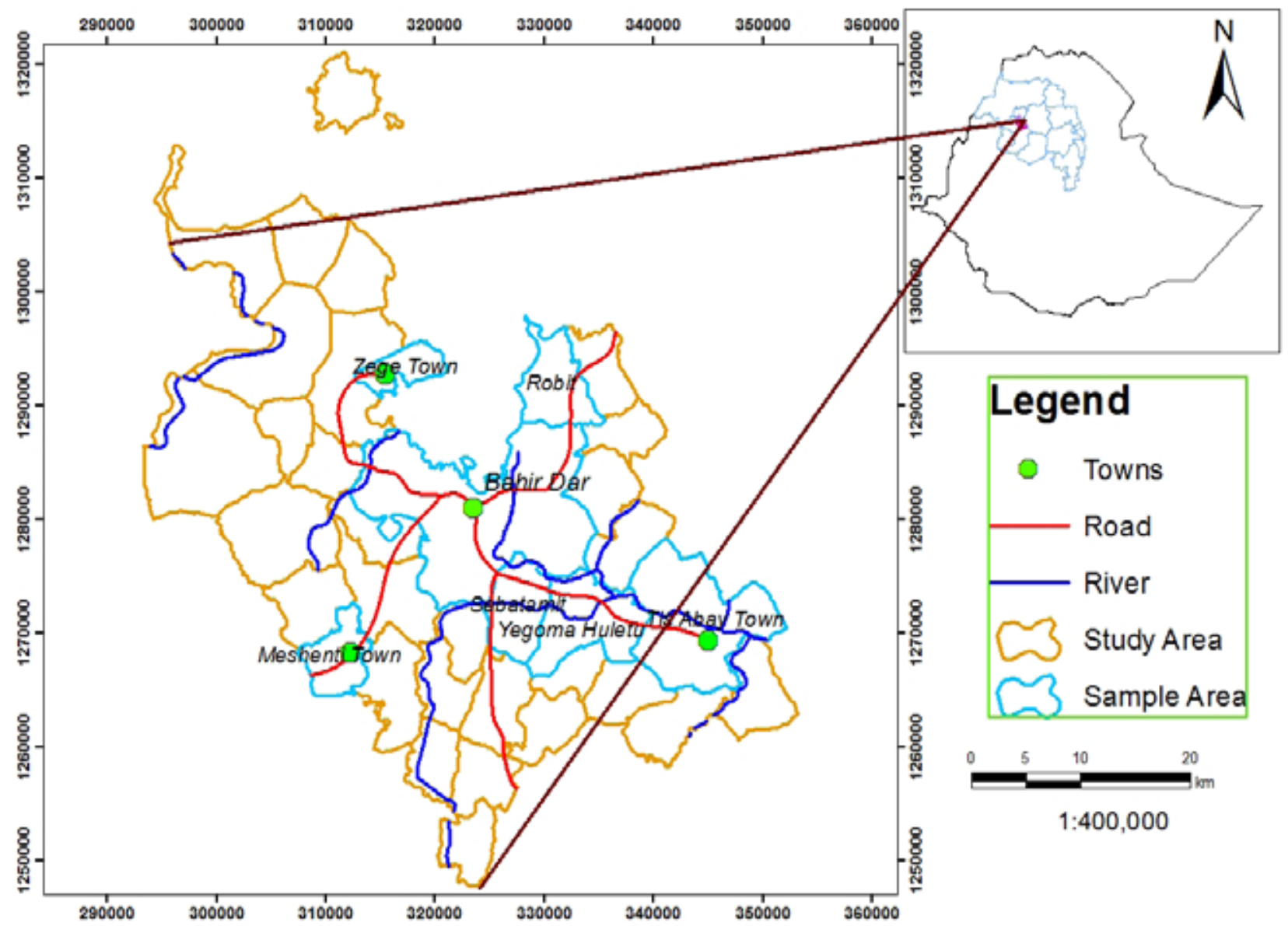

Figure 1. Map of Bahir Dar City and kebeles bound Bahir Dar (CACC, 2003) 


\section{Study design and study population}

A cross-sectional study design was conducted to assess household level milk hygienic practices and child milk consumption.

\section{Sampling of milk and quality analysis}

A total of 30 milk samples were collected from each site based on primary survey $(n=90)$. Therefore, a total of 79 samples were tested. Milk samples were collected from households producing milk that is provided to their child based on the result of the preliminary survey. The milk sample was taken from the cup that a child used to drink from, before it was boiled and the volume of milk was measured with measuring cylinder.

Sample collecting bottles and measuring cylinder were obtained from Andassa Livestock Research Center. The bottles and measuring cylinder were sterilized with autoclave by washing with detergent and boiled water. Sterilization of sample collecting bottle was performed before and after sample collection from each three sites. The collected milk samples were mixed together into sterilized universal bottles of about $1000 \mathrm{ml}$ capacity and labeled the name of the site on the bottle. From each house $33 \mathrm{ml}$ of milk was collected. The milk for from sub clinical mastitis test was taken directly from the cow while for quality analysis it was taken from the cup that the child used to drink from. The collected milk was delivered to Bahir Dar Regional Veterinary Laboratory 30 minute after collection in ice box, then the mastitis test was completed for 1 hour and 30 minutes then the milk samples which passed the mastitis test was delivered to Bahir Dar University Food and Biochemical Technology Department within the ice box for milk quality analysis. All milk quality analysis was performed immediately after delivery. Microbial counts were made after 24 hours.

The microbial tests considered Standard Plate Count (SPC), Coliform Count (CC), titratable acidity, alco- hol test and lactometer test. The corresponding SPC and $\mathrm{CC}$ were computed from duplicate plates containing between 25-250 colonies. Plates containing less than 25 colonies were taken as less than 25 estimated counts and plates containing greater than 250 colonies for all dilutions were recorded as Too numerous to count (TNTC). The colonies were counted with colony counter. For analysis purpose only counts in the normal (25-250) were taken directly. When all plates counted less than 25 , the nearest count to 25 was taken and when all plates counted greater than 250 colonies for all dilutions, the nearest colony count to 250 was taken (APHA, 1992). To avoid a fictitious impression of precision and accuracy when computing the counts, only the first two significant digits were reported by rounding up or down to the next number. The following formula was used to calculate the counts (APHA, 1992).

$$
\mathrm{N}=\frac{\Sigma \mathrm{C}}{[(1 \times n 1)+(0.1 \times n 2)] d}
$$

Where:

$\mathrm{N}=$ Number of colonies per $\mathrm{ml}$ or $\mathrm{g}$ of product; $\Sigma \mathrm{C}=$ Sum of all colonies on all plates counted; $n 1=$ Number of plates in first dilution counted; $\mathrm{n} 2=$ Number of plates in second dilution counted $\mathrm{d}=$ Dilution from which the first counts were obtained.

\section{Coliform count (CC)}

The CC was made by mixing $25 \mathrm{ml}$ of milk sample into sterile stomacher bag having $225 \mathrm{ml}$ peptone water $(1 \%)$. After mixing, the sample was serially diluted up to $10^{-4}$ in sterile test tubes having $9 \mathrm{ml}$ of peptone water and duplicate samples $(1 \mathrm{ml})$ were plated using 15-20 ml Violet Red Bile Agar (VRBA) in sterile petri dish. After thoroughly mixing, the plated sample was allowed to solidify and then incubated at $30^{\circ} \mathrm{C}$ for 24 hours. Finally, colony counts were made using colony counter. Typical dark red colonies were considered as coliform colonies (MMAF, 2012). 


\section{Standard plate count (SPC)}

The SPC was made by adding $25 \mathrm{ml}$ of milk sample into sterile stomacher bag having $225 \mathrm{ml}$ peptone water $(1 \%)$. After thoroughly mixing, the sample was serially diluted up to $10^{-4}$ in sterile test tubes having 9 $\mathrm{ml}$ peptone water and duplicate samples $(1 \mathrm{ml})$ were pour plated using 15-20 ml SPC agar solution and mixed thoroughly. The plated sample was allowed to solidify and then incubated at $30^{\circ} \mathrm{C}$ for 48 hours. Colony counts were made using colony counter (MMAF, 2012). After incubation, all colonies including those of pin point size in SPCA medium and purplish red colonies in VRBA medium.

\section{Titratable acidity test}

Titratable acidity is a measure of freshness and bacterial activity in milk. The production of acid in milk is normally termed souring and the sour taste of such milk is due to production of lactic acid. The percentage of acid present in dairy products at any time is a rough indicator of the age of the milk and the manner in which it has been handled (Monika and Poonam, 2013). Acidity was measured by titration with $0.1 \mathrm{~N}$ sodium hydroxide solutions and using 1\% ethanol solution of phenolphthalein as indicator (O'Connor, 1994). The following formula was used to calculate the lactic acid percentage (O'Connor, 1995).

\section{Lactic acid $(\%)=\underline{\mathrm{ml} \mathrm{N} / 10 \text { alkali } \times 0.009 \times 100}$ $\mathrm{ml}$ of sample}

\section{Alcohol test}

Five $\mathrm{ml}$ of milk and $5 \mathrm{ml}$ of $68 \%$ alcohol (ethanol) were placed in a test tube. The test tube was inverted several times with the thumb held tightly over the open end of the tube. The tubes were shaken to mix and any clot formation was noted (Ombui et al., 1995). Clot formation indicates absence of freshness of the milk

\section{Specific gravity test}

Milk sample was filled gently into a measuring cylinder at room temperature. Then alacto meter was placed to sink slowly into the milk. The reading was taken just above the surface of the milk. According to the method described by Kurwijila (2006), these calculations are done on the lactometer readings.

The following formula was used to calculate the milk specific gravity.

\section{Specific gravity $=\frac{L c}{1000}$}

Where, Lc - Lactometer reading at a given temperature, i.e., for every degree above $60^{\circ} \mathrm{F}, 0.1$ degree was added, but for every degree below $60^{\circ} \mathrm{F}, 0.1$ degree was subtracted from the lactometer reading (O’Mahony, 1988).

Normal milk has specific gravity of 1.026-1.032 g/ $\mathrm{ml}$ (or 26-32 on the lacto meter reading). If water has been added, the lactometer reading would be below 26. If any solid such as flour has been added, the reading will be above 32 (Kurwijila, 2006).

\section{Statistical analysis}

The collected data was directly entered to statistical package for social sciences version 20 software and were analyzed with this software. Descriptive statistics were employed to summarize milk handling and boiling practice. Analysis of variance (ANOVA) procedure was used to measure location effects on measured quality parameters. P-value $\leq 0.05$ were considered to have significant difference.

\section{RESULTS}

\section{Milking, milk handling and boiling practices}

In the study area, cows were hand milked and calves are allowed to suckle their dams prior milking. The 
usual practice is to let the calves suckle their dams for a few minutes to stimulate milk let down. Milking the cow was at a standing position with one knee raised to support the milking vessel on their lap while another person holding the calf from suckling.

According to this study, in the urban area, $56 \%$ of respondents' wash the cow udder whereas the proportions of respondents who practice udder washing prior to milking were $22 \%$ and $2 \%$ in periurban and rural areas, respectively. All of the interviewed respondents wash hands and milking vessels before milking cows. However, dipping of milker's fingers into the milking vessel and moistening teats of the cows to facilitate milking were practiced in the study area. In this finding, the use of towel and hand glove to clean the udder of the cow and to keep the milk quality is very limited. In this finding $88.7 \%, 67.3 \%$ and $45.2 \%$ of respondents has a practice of milk boiling before feeding the milk to their children in the urban, peri-urban and rural areas of the study, respectively. On the other hand, $11.3 \%$ in the urban, peri-urban $32.7 \%$ and in the rural $54.8 \%$ of respondents do not have milk boiling practice before giving the milk to their children (Table 1).

Table 1. Milking procedure in and around Bahir Dar

\begin{tabular}{lccc}
\hline Variables & Urban $(\mathrm{N}=50)$ & Peri urban $(\mathrm{N}=50)$ & Rural $(\mathrm{N}=50)$ \\
\cline { 2 - 4 } & $\%$ & $\%$ & $\%$ \\
\hline Milking procedure & & & 100 \\
\hline Wash the hand and milking vessels & 100 & 22 & 2 \\
Washing the udder before milking & 56 & 78 & 98 \\
Do not wash the udder & 44 & & 100 \\
\hline Use glove & 20 & 100 & \\
\hline Glove users for milking & 80 & & \\
Do not use glove for milking & & & \\
\hline
\end{tabular}

$\mathrm{N}=$ Number of respondents

\section{Microbiological quality of milk}

Higher $(\mathrm{SPC} / \mathrm{ml})$ was found in the rural $5 \times 10^{5}$ areas of the study compared to the urban and peri-urban sites. However, there was no significant difference in mean SPC/ml ( $p>0.05)$ across locations. Likewise, of SPC, higher CC $\left(2.2 \times 10^{5}\right)$ was obtained in the rural area of the study without significant $(\mathrm{p}>0.05)$ difference across location (Table 2).

Table 2. Microbial quality of cow raw milk in and around Bahir Dar

\begin{tabular}{lllll}
\hline Location & SPC $(\mathrm{CFU} / \mathrm{ml})$ & $\mathrm{SPC}\left(\log _{10}\right)$ & $\mathrm{CC}(\mathrm{CFU} / \mathrm{ml})$ & $\mathrm{CC}\left(\log _{10}\right)$ \\
\hline Urban & $10^{4}$ & 4 & $4.7 \times 10^{3}$ & 3.7 \\
Peri urban & $4.6 \times 10^{4}$ & 4.7 & $3.1 \times 10^{4}$ & 4.5 \\
Rural & $5 \times 10^{5}$ & 5.7 & $2.2 \times 10^{5}$ & 5.3 \\
\hline
\end{tabular}

$\mathrm{SPC}=$ standard plate count, $\mathrm{CC}=$ coliform count, $\mathrm{CFU}=$ colony forming unit 
In this stud it was found that the milk in the urban area was under the range which indicates addition of water whereas, milk consumed by peri-urban and rural children was not adulterated. However, no significant difference was observed ( $p>0.05)$ in specific gravity across locations (Table 3 ).

Table 3. Physico-chemical quality of cow raw milk in and around Bahir Dar

\begin{tabular}{lll}
\hline Location & $\begin{array}{l}\text { Mean values of milk physico-chemical quality parameters across the } \\
\text { studyworedas }\end{array}$ \\
\cline { 2 - 3 } & Adulteration & Acidity test \\
\cline { 2 - 3 } & Mean \pm SD & Mean \pm SD \\
\cline { 2 - 3 } Urban & $25.00^{\mathrm{a}} \pm 0.00$ & $0.19^{\mathrm{a}} \pm 0.01$ \\
Peri-urban & $26.67^{\mathrm{a}} \pm 0.58$ & $0.20^{\mathrm{a}} \pm 0.10$ \\
Rural & $26.11^{\mathrm{a}} \pm 0.58$ & $0.23^{\mathrm{a}} \pm 0.02$ \\
Over all & $26.11 \pm 0.93$ & $0.21 \pm 0.02$
\end{tabular}

$\mathrm{SD}=$ Standard Deviation, Means followed with different superscripts in a column are significantly different $(\mathrm{P}<0.05)$

\section{DISCUSSION}

Provision of milk and milk products of good hygienic quality is desirable from consumer health point of view (Zelalem Yilma, 2010). The mean value of SPC/ $\mathrm{ml}$ in urban, peri-urban and rural areas of the study was similar and was below the minimum quality standard value $\left(2 \times 10^{6} \mathrm{SPC} / \mathrm{ml}\right)$ established for Ethiopia (ES, 2009). The SPC obtained in this study was also lower than the report of Asaminew Tassew and Eyassu Seifu(2007), Solomon et al. (2013), who reported in Bahir Dar zuria and Mecha woreda and selected dairy farms in Debre Zeit town, respectively. Similarly, the total coliform count did not vary between the three study sites. The CC which was obtained in the three sites of the study was lower than the report of Zelalem Yilma and Bernard (2006) done on different producers in the central highland of Ethiopia. However, according to American and European community member states, the acceptable limit for CC for raw milk was 150cfu/ml (APHA, 1992). Therefore, milk collected from all study sites does not meet the minimum quality standard as the coliform population is much higher than the value indicated which may suggest the need for further investigation on the presence of human pathogenic bacteria in milk in the study areas.

The higher CC may be due to the initial contamination of the milk samples either from the cows, milkers' hands, milk containers or milking environment in general (Asaminew Tassew and Eyassu Seifu, 2007). In agreement with this suggestion, this study has established the presence of potential risk factors such as udder hygiene, proper hand washing and cleanness of milking and storage utensils that might predispose the milk to contamination. For example, maximum reduction of teat contamination of $90 \%$ can be achieved with good udder preparation (washing with disinfectant and drying with paper towel) before milking (Abebe et al., 2012). Before milking cows, dipping of milker's fingers into the milking vessel and moistening teats of the cows to facilitate milking is practiced in the study area. This practice may allow microbial contamination of the milk from the milker's hand and thus should be discouraged (Asaminew Tassew and Eyassu Seifu, 2007). 
Titratable acidity is a measure of freshness and bacterial activity in milk. Popescu and Angel (2009) reported that, high quality milk essentially needs to have less than $0.14 \%$ acidity. Therefore, milk collected from all study sites does not meet the minimum quality standard of acidity as it was much higher than the value indicated. However, the overall mean titratable acidity of cows' milk produced in the study area was 0.21. This figure is lower than the finding of Asaminew Tassew and Eyassu Seifu (2007) who reported an average acidity of 0.23 in Bahir Dar and Mecha woreda. Similarly, this finding was lower than the report of Alganesh Tolla (2002) who reports 0.28 and 0.31for raw cows' milk produced in BilaSayo and GutoWayu woredas of eastern Wollega, respectively. Acidity of the milk samples did not show significant variation $(\mathrm{P}>0.05)$ by location. Fresh milk can have an initial acidity because of the buffering capacity (O’Mahony, 1988), but the milk tested was kept long at ambient temperature between milking and analysis attributing to high acidity. According to Monika and Poonam (2013), the percentage of acid present in dairy product at any time is a rough indication of the age of milk and the manner in which it has been handled.

When milk contains more than $0.21 \%$ acid, or when calcium or magnesium compound are present in greater than normal compounds, it coagulates on the addition of alcohol. This fact is the basis of alcohol test, which furnishes a means of judging the quality of milk (Ombui et al., 1995). Therefore, children in the urban and peri urban area consumes fresh milk while, in the rural children consumes milk which is not fresh. Normal milk has specific gravity of 1.026$1.032 \mathrm{~g} / \mathrm{ml}$ (or 26-32 on the lactometer reading). If the milk is adulterated, the lactometer reading will be below 26. If any solid such as flour has been added, the reading will be above 32 (Kurwijila, 2006). Therefore, a child in the urban area consumes adulterated milk whereas; milk consumed by peri-urban and rural children was not adulterated. Adulteration of milk reduces the quality of milk.

\section{CONCLUSIONS}

From this study, it was noted that the quality of milk fed to children by dairy cow owners was found to be affected by factors such as udder hygiene, cleanness of hands and utensils which might have ultimately resulted in higher coliform counts in milk of all study sites. Awareness should be created among households with dairy cow as to the importance of hygienic milk production, handling, feeding and processing. Areas of concern are proper washing and drying of the udder, hand washing before milking, proper cleaning of milking and storage vessels as well as child feeding utensils .Further study is required to investigate human pathogenic microbes in milk as the coliform level was found high. Moreover, similar study on the quality of milk provided to children in households without dairy cows is recommended.

\section{REFERENCES}

Abebe, B., Zelalem Yilma and Ajebu, N. (2012). Hygienic and microbial quality of raw whole cow's milk produced in Ezha district of the Gurage zone, Southern Ethiopia. Wudpecker Journal of Agricultural Resources 1(11):459465.

Alganesh Tola. (2002). Traditional milk and milk products handling practices and raw milk quality in Eastern Wollega. MSc. Thesis, Alemaya University, Dire Dawa, Ethiopia.

American Public Health Association (APHA) (1992): Standard Method for the Examination of Dairy Products. 16th Ed, American Public Health Association (APHA), Washington.

Amhara Livelihood Report Zone (ALZR). (2012/13). Bahir Dar Z woreda West Gojjam Administration Zone, Amhara Livelihood Zone Report (ALZR), Bahir Dar, Ethiopia.

Asaminew Tassew and Eyassu Seifu. (2007). Microbial quality of raw cow's milk collected 
from farmers and dairy cooperatives in Bahir

Dar Zuria and Mecha District, Ethiopia. Agriculture and Biology Journal of North America 2(1): 29-33.

Asaminew Tassew. (2007). Production, handling, traditional processing practices and quality of milk in Bahir Dar milk shed area. MSc. Thesis Haramaya University, Ethiopia.

Barasa, M. (2008). Foot-and-mouth disease vaccination in South Sudan: benefit-cost analysis and livelihoods impact. Transboundary Emerging Diseases 55: 339-351.

BCAO. (2012/13). Census data report on human, livestock population living in and around Bahir Dar, Bahir Dar City Agricultural Office (BCAO), Bahir Dar, Ethiopia.

Bisrat Godefay and Bayileyegn Molla. (2000). Bacteriological quality of raw cow's milk from four dairy farms and a milk collection center in and around Addis Ababa. Berliner Und Münchener Tierärztliche Wochenschrift 113:276-278.

BoARD. (2006). Bureau of Agriculture and Rural Development (BoARD) Amhara Region, Statistics Section. Bahir Dar, Ethiopia.

BoFED. (2008): Amhara National Regional State. Annual Statistical Bulletin.Bureau of Finance and Economic Development (BoFED), Bahir Dar, Ethiopia.

BZOARD. (2007). Annual Budget Report of Bahir Dar Zuria Office of Agriculture and Rural Development (BZOARD), Bahir Dar, Ethiopia. Central Agricultural Census Commission (CACC), (2003). Ethiopian Agricultural Sample Enumeration, 2001/ 02. Results for Amhara Region, Statistical Reports on Livestock and Farm Implants (Part IV), Central Agricultural Census Commission (CACC), Addis Ababa, Ethiopia. Pp. 45-46.

Kurwijila, L. (2006). Hygienic milk handling, processing and marketing: reference guide for training and certification of small-scale milk traders in Eastern Africa. ILRI (International Livestock Research Institute), Nairobi, Kenya. Manuals of Methods of Analysis of Food (MMAF) (2012). Food Safety and Standards Authority of Indian Ministry of Health and Family Welfare Government of India New Delhi. Manuals of Methods of Analysis of Food (MMAF), Lab. Manual 14.

Monika, S and Poonam, R. (2013). Microbiological And Chemical Analysis Of Raw, Pasteurized And UHT Milk During Preservation In India. Department of Applied Chemistry, Bansal Institute of Research, Technology and Science, Bhopal, India. International Journal of Chemical Technology Resources 5(6):28042809.

O’Connor, C. (1994). Rural dairy technology. ILRI training manual No. 1.International Livestock Research Institute (ILRI), Addis Ababa, Ethiopia.Pp.133.

O’Connor, C. (1995). Rural Dairy Technology. ILRI Training Manual. ILRI, Addis Ababa, Pp. 29$30,80,85-86$.

O’Mahony, F. (1988). Rural dairy technology experiences in Ethiopia. ILCA Manual No. 4.Dairy Technology Unit. ILCA, Addis Ababa, Ethiopia.Pp.64.

Ombui, J., Arimi, S., Mcdermott, J., Mbugua, S., Githua, A and Muthoni, J. (1995). Quality of raw milk collected and marketed by dairy cooperative societies in Kiambu Woreda, Kenya. Bulletin Animal, Health Production in Africa 43: 277-284.

Parekin, T and Subhash, R. (2008). Molecular and bacteriological examination of milk from different animals with special reference to coliforms. Current Research Bacteria 1(2):5663.

Quantification and Characterization (QCB) (2010). Waste Quantification and Characterization Bahir Dar, Quantification and Characterization -Bahir Dar (QCB), Bahir Dar, Ethiopia. 
Solomon Mosu, Mulisa Megersa, Yibeltal Muhie, Desalegn Gebremedin and Simenew Keskes (2013). Bacteriological quality of bovine raw milk at selected dairy farms in Debre Zeit town, Ethiopia. Comprehensive Journal of Food Science and Technology Research 1(1): 1 - 8.

Zelalem Yilma (2010). Microbial Properties of Ethiopian Marketed Milk and Milk Products and Associated Critical Points of Contamination: An Epidemiological Perspective, Addis Ababa, Ethiopia.

ZelalemYilma and Bernard, F. (2006). Handling and Microbial Load of Cow's Milk and Irgofermented Milk Collected from Different Shops and Producers in Central Highlands of Ethiopia. Dairy Technol, Ethiopian Institute of Agric. Res., Holetta Agricultural Res. Center, Addis Ababa, Ethiopia. Ethiopian Journal Animal Production 6(2): 67-82. 